\title{
Canine ehrlichiosis: clinical, hematological, serological and molecular aspects
}

\author{
Erliquiose canina: aspectos clínicos, hematológicos, sorológicos e moleculares
}

\author{
Andréa Cristina Higa Nakaghi ${ }^{I}$ Rosangela Zacarias Machado ${ }^{I^{*}}$ Mirela Tinucci Costa ${ }^{I I}$ \\ Marcos Rogério André ${ }^{1}$ Cristiane Divan Baldani ${ }^{I}$
}

\section{ABSTRACT}

The aim of the present study was to compare the direct detection methods of Ehrlichia canis (blood smears and nested PCR), serological tests (Dot-ELISA and Immunofluorescent Antibody Test - IFAT), and demonstrate the most suitable test for the diagnosis of different stages of infection. Blood samples and clinical data were collected from 30 dogs examined at the Veterinary Teaching Hospital, UNESP, Jaboticabal, SP, Brazil. The clinical signs most frequently observed were apathy, anorexia, pale mucous membrane, fever, lymphadenopathy, splenomegaly, hemorrhages and uveitis. Evaluating the humoral immune response, $63.3 \%$ of the sera were IFAT positive, while $70 \%$ were Dot-ELISA positive. By nestedPCR $53.3 \%$ of the samples were positive. Comparing these techniques it was concluded that serology and nPCR are the most suitable tests to confirm the diagnosis of canine ehrlichiosis, however it should be always treated as a complementary data to clinical and hematological evaluation. Serology has an important role in the subclinical and in the chronic phase, nPCR is recommended in the acute stage, and, especially, to identify the ehrlichia specie.

Key words: Ehrlichia canis, dog, IFAT, Dot-ELISA, nested PCR.

\section{RESUMO}

O objetivo deste estudo foi comparar técnicas para detecção direta de Ehrlichia canis (detecção de mórulas em esfregaço sangüíneo e nested PCR), testes sorológicos (DotELISA e Reação de Imunofluorescência Indireta - RIFI) $e$ identificar o teste mais adequado para o diagnóstico de diferentes fases da infecção. Amostras sangüíneas e dados dos prontuários clínicos foram colhidos de 30 cães examinados no Hospital Veterinário, UNESP - Jaboticabal, SP. Os sinais clíncos mais freqüentemente observados foram apatia, inapetência, palidez de mucosas, febre, linfadenopatia, esplenomegalia, hemorragias e uveíte. Na avaliação da resposta imune humoral, observou-se que 63,3\% das amostras foram positivas na RIFI, e 70\% no Dot-ELISA. Na nPCR, foram detectadas 53,3\% de amostras positivas. Ao comparar estas técnicas, concluiu-se que a sorologia e a nPCR são testes adequados para a confirmação do diagnóstico da erliquiose canina. Entretanto, os resultados destas técnicas devem sempre ser complementares ao exame clínico e hematológico. A sorologia tem um importante papel nas fases subclínica e crônica da doença, por isso recomenda-se a nPCR para o diagnóstico na fase aguda e, especialmente, para a identificação da espécie de erliquia envolvida.

Palavras-chave: Ehrlichia canis, cão, RIFI, Dot-ELISA, nested PCR.

\section{INTRODUÇÃO}

Ehrlichia canis, a canine monocitic ehrlichiosis agent is a Gram-negative coccoid to ellipsoidal bacteria, occurring intracytoplasmically, either singly or in compact inclusions (morulae) in dog bone marrow derived cells. The canine monocytic ehrlichiosis was described for the first time in Algeria in 1935 by Donatien and Lestoquard and, nowadays, it has a worldwide distribution. In Brazil, canine monocitic ehrlichiosis was first described in Belo Horizonte in 1973 (COSTA, 1973) and in dogs, E. canis is the most common specie (OLIVEIRA et al., 2000; DAGNONE et al., 2003).

Specific diagnostic tests for canine ehrlichiosis include demonstration of intracytoplasmic E. canis-morulae within monocytes, culturing, serology IDepartamento de Patologia Veterinária, Faculdade de Ciências Agrárias e Veterinárias (FCAV), Universidade Estadual de São Paulo
(UNESP), 14884-900, Jaboticabal, SP, Brasil. E-mail: zacarias@fcav.unesp.br. *Autor para correspondência.

IDepartamento de Clínica e Cirurgia Veterinária, FCAV, UNESP, Jaboticabal, SP, Brasil. 
and PCR. The detection of the $\boldsymbol{E}$. canis morulae is uncommon except during the acute phase of the infection (HIBBLER et al., 1986). The direct detection of $\boldsymbol{E}$. canis is difficult even though the samples are positive through serology(OLIVEIRA et al., 2000). The serological detection of anti-E. canis antibodies may be performed by Indirect Fluorescent Antibody Test (IFAT) or Dot-ELISA (CADMAN et al., 1994). IFAT is the serological assay most widely used for the diagnosis of canine ehrlichiosis (WANER et al., 2001). Improvements in molecular biology techniques have led to the development of DNA detection of $\boldsymbol{E}$. canis for the diagnosis of ehrlichiosis. The DNA amplification through PCR has provided a more sensitive, specific and reliable direct diagnosis (IQBAL et al., 1994).

This study compared the direct detection methods of E. canis (blood smears and nested PCR) and serological tests (Dot-ELISA and Indirect Immunofluorescent Antibody Test - IFAT), and analyzed clinical and hematological signs of dogs suspected of ehrlichiosis. The aim of this study was to demonstrate the most suitable test for the diagnosis of different $\boldsymbol{E}$. canis stages of infection.

\section{MATERIALS AND METHODS}

Animals - Thirty dogs were selected at the Veterinary Teaching Hospital, UNESP, Jaboticabal, SP, according to their clinical signs (apathy, anorexia, fever, petechial and ecchymotic hemorrhages, lymphadenopathy, splenomegaly, paleness mucous membranes and/or uveitis) or hematological findings (anemia, leukopenia and/or thrombocytopenia) in an acute or chronic disease stage. Blood samples were collected for hematology and nPCR, and serum samples were tested for $\boldsymbol{E}$. canis antibodies by IFAT and DotELISA. Positive controls were obtained from an $\boldsymbol{E}$. canis experimentally-infected dog and negative controls obtained from the same dog before the infection.

Serology - IFAT was used to detect $\boldsymbol{E}$. canis IgG antibodies. The technique was performed according to the manufacturer's recommendations $\left(\mathrm{VMRD}^{\circledR}\right.$, Inc.). Sera were diluted 1:20 in saline solution and the used conjugate was a rabbit IgG anti-dog IgG, diluted according to the manufacturer's recommendations $\left(\right.$ Sigma $\left.^{\circledR}\right)$. Scores were attributed to fluorescence intensity in the analyzed sera: negative (-), positive $(+)$, and highly positive $(++)$. Sera were also tested by Dot-ELISA using Immunocomb ${ }^{\circledR}$ BIOGAL kit in order to detect anti-E.canis IgG antibodies.

nPCR assay - DNA was extracted with QIAamp DNA Blood Mini Kit $\left(\right.$ Qiagen $\left.^{\circledR}\right)$, according to the manufacturer's recommendations. The Ehrlichia genus amplification was performed using ECC (5'GAACGAACGCTGGCGGCAAGC-3') and ECB (5'CGTATTACCGCGGCTGCTGGCA-3') primers, and HE3 (5' - TATAGGTACCGTCATTATCTTCCCTAT -3') and ECAN (5'-CAATTATTTATAGCCTCTGGCTATAGGA3') primers were used to amplify the E. canis $16 \mathrm{~S}$ rRNA gene (WEN et al., 1997; MURPHY et al., 1998). Reaction $(50 \mu \mathrm{L})$ contained $5 \mu \mathrm{L}$ of template DNA in $5 \mu \mathrm{L}$ PCR buffer 10X (100mM Tris-HCl, pH 9.0, 500mM KCl), $0.2 \mathrm{mM}$ each dNTP, $2.5 \mathrm{mM} \mathrm{MgCl}_{2}$, $1 \mathrm{pmol}$ each primer, $1.25 \mathrm{U}$ of Taq DNA polymerase and it was performed as described previously (MURPHY et al., 1998). The nPCR assay used the same reaction conditions as the first amplification, but specie-specific primers were used and $1 \mu \mathrm{L}$ from the initial PCR was used as template. The sensitivity of the nPCR reaction was analyzed from an E. canis-infected DH82 with 100\% rickettsemia diluted 10 -fold in distillated water.

The chi-square test $\left(x^{2}\right)$ was used in order to compare IFAT, Dot-ELISA and nPCR.

\section{RESULTS}

According to the clinical data from 30 dogs, the most frequently observed clinical signs were apathy $(60.7 \%)$, anorexia $(56.7 \%)$, pale mucous membrane (43.3\%), fever (43.3\%), lymphadenopathy (43.3\%), hepatomegaly and/or splenomegaly (43.3\%), hemorrhages (petechial and epistaxis) $(33.3 \%)$ and uveitis (40\%). Direct detection of the intracytoplasmatic E. canis morulae in blood smears was possible in only one $(3.3 \%)$ out of the 30 samples examined.

In the IFAT, $19(63.3 \%)$ sera showed positive titer for E. canis, while 11 (36.6\%) were negative. By Dot-ELISA, 21 (70\%) sera presented titers higher than $1: 20$, considered as positive, while $9(30 \%)$ were negative. No significant difference was observed when comparing IFAT, Dot-ELISA and nested PCR results (Table 1).

Nested PCR positive samples were demonstrated by the amplification of a 398bp fragment from 16S rRNA gene of E. canis (Figure 1). This PCR system was able to detect $\boldsymbol{E}$. canis DNA with an equivalent rickettsemia of $1 \times 10^{-34 \%} \%$. Among 30 samples, this fragment was observed in $16(53.3 \%)$ while 14 $(46.6 \%)$ were negative. Only two samples were conegative by nPCR, Dot-ELISA and IFAT. The other 28 samples were positive for detection of $\boldsymbol{E}$. canis in at least one test.

The tests results from these 28 positive dogs were analyzed with clinical (Table 2) and hematological signs (Table 3 ). The positive sample by direct detection 
Table 1 - Association between Dot-ELISA, nPCR and IFAT* results from 28 dogs suspected to be infected with Ehrlichia canis and examined at the Veterinary Teaching Hospital, UNESP, Jaboticabal, SP, Brazil.

\begin{tabular}{|c|c|c|c|c|c|c|}
\hline \multicolumn{7}{|c|}{ TOTAL } \\
\hline \multicolumn{3}{|c|}{ IFAT Positive $(\%) n=19$} & \multicolumn{3}{|c|}{ IFAT Negative $(\%) n=11$} & \multirow[t]{3}{*}{$\mathrm{n}=30$} \\
\hline Dot- & \multicolumn{2}{|c|}{ nPCR } & Dot- & \multicolumn{2}{|c|}{ nPCR } & \\
\hline ELISA & Positive & Negative & ELISA & Positive & Negative & \\
\hline Positive & $8(42.1)$ & $10(52.6)$ & Positive & $1(9.1)$ & $2(18.1)$ & $21(70)$ \\
\hline Negative & $1(5.27)$ & 0 & Negative & $6(54.5)$ & $2(18.1)$ & $9(30)$ \\
\hline Total & $9(30)$ & $10(33.3)$ & TOTAL & $7(23.3)$ & $4(13.4)$ & $30(100)$ \\
\hline
\end{tabular}

*IFAT - Imunofluorescent Antibody Test.

of intracytoplasmatic $\boldsymbol{E}$. canis morulae in blood smears was also IFAT and nPCR positive, but Dot-ELISA negative.

\section{DISCUSSION}

Canine ehrlichiosis is an infectious disease with a high incidence. $\boldsymbol{E}$. canis can be detected for a short period of time in monocytes but they cannot be found during subclinical and chronic stages of infection. Even so, the search for morulae in circulating monocytes is still the routine diagnostic method for ehrlichiosis (MOREIRA et al., 2005) but in most cases unrewarding. The diagnostic is, in some cases, a combination of clinical and hematological signs (COHN, 2003), but this signs may be confusing and variable (WANER et al., 2001).

The clinical signs most frequently observed in the dogs suspected to be infected with $\boldsymbol{E}$. canis were also noted by other authors in natural (HARRUS et al., 1999; OLIVEIRA et al., 2000) and in experimental infections (CASTRO et al., 2004).

No statistical difference was observed when comparing between IFAT and Dot-ELISA results. Previous studies demonstrated a higher sensitivity of Dot-ELISA when compared to IFAT, although both methods are qualitatively efficient in detecting anti-E. canis antibodies (CADMAN et al., 1994; OLIVEIRA et al., 2000; HARRUS et al., 2002). The Israeli isolate, used in Dot-ELISA, was $0.54 \%$ different from the Oklahoma strain used in IFAT (KEYSARY et al., 1996). Besides the high sensitivity, Dot-ELISA is a rapid technique and easy to be used in clinical routine for the diagnosis of ehrlichia. Conflicting results between IFAT, ELISA and Western blot were observed in low-titer serum samples, and these results may reflect enhanced IFAT sensitivity and poor IFAT specificity associated with cross-reactivity among Ehrlichia spp (O'CONNOR, et al, 2006).

Nested PCR was used to detect $\boldsymbol{E}$. canis DNA in the dog's blood samples. The test detected $53.3 \%$ positive samples, showing that $\boldsymbol{E}$. canis is common in Jaboticabal region. Similar results were found in dog's blood samples tested by PCR to detected E. canis, E. chaffeensis, Anaplasma platys, A. phagocytophilum and Neorickettsia risticii in the same region (DAGNONE et al., 2006). The nPCR sensitivity was evaluated and it could detect $\boldsymbol{E}$. canis DNA until an equivalent rickettsemia of one infected monocyte in $10^{36}$ cells. The high sensitivity of the PCR to detect $\boldsymbol{E}$. canis was already shown (McBRIDE

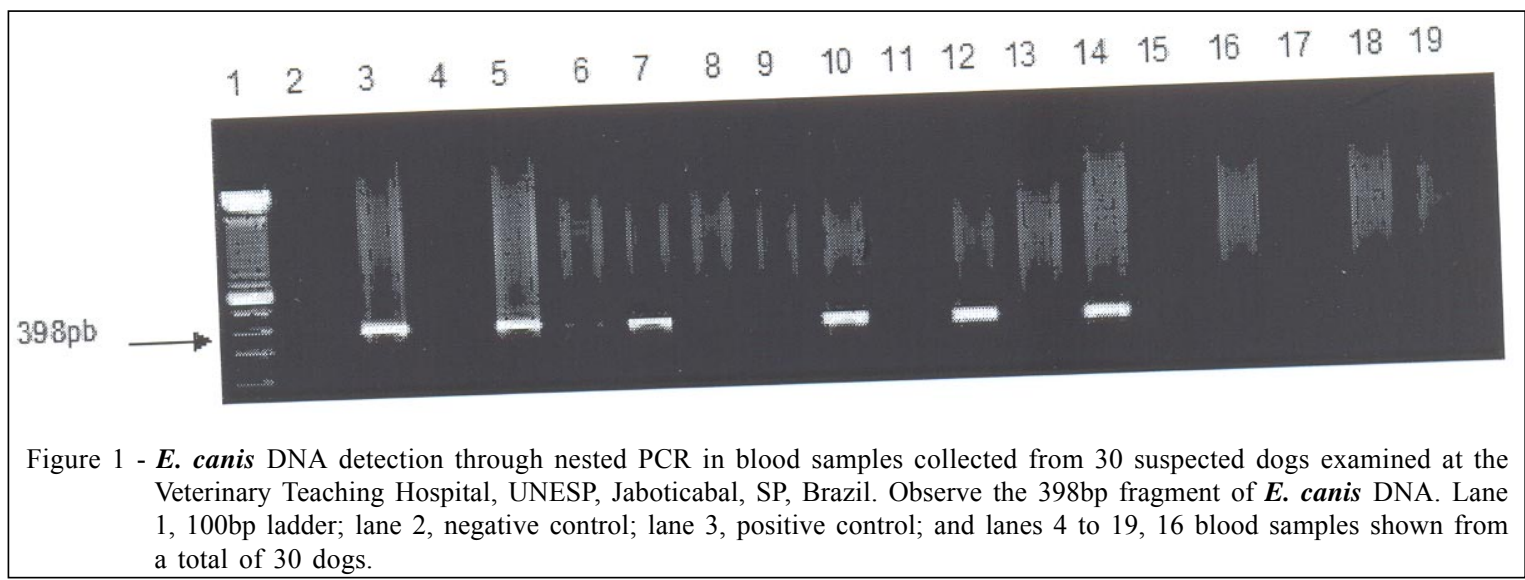

Ciência Rural, v.38, n.3, mai-jun, 2008. 
Table 2 - Association between clinical signs and IFAT*, Dot-ELISA and nPCR results from naturally E. canis infected dogs examined at the Veterinary Teaching Hospital, UNESP, Jaboticabal, SP, Brazil.

\begin{tabular}{|c|c|c|c|c|c|c|}
\hline \multirow{3}{*}{ Clinical signs (total) } & \multicolumn{4}{|c|}{ Serology } & \multirow{2}{*}{\multicolumn{2}{|c|}{ nPCR (\%) }} \\
\hline & \multicolumn{2}{|c|}{ IFAT (\%) } & \multicolumn{2}{|c|}{ Dot-ELISA (\%) } & & \\
\hline & Positive & Negative & Positive & Negative & Positive & Negative \\
\hline Apathy (18) & $12(66.6)$ & $6(33.3)$ & $13(72.2)$ & $5(27.7)$ & $11(61.1)$ & $7(38.8)$ \\
\hline Inappetency (16) & $10(62.5)$ & $6(37.5)$ & $12(75)$ & $4(75)$ & $11(68.7)$ & $5(31.2)$ \\
\hline Hipertermia (12) & $9(75)$ & $3(25)$ & $10(83.3)$ & $2(16.1)$ & $8(66.6)$ & $4(33.3)$ \\
\hline Pale mucous membrane (13) & $8(61.5)$ & $5(38.4)$ & $10(76.9)$ & $3(23)$ & $7(53.8)$ & $6(46.1)$ \\
\hline Hemorrhage (8) & $8(100)$ & $0(0)$ & $8(100)$ & $0(0)$ & $3(37.5)$ & $5(62.5)$ \\
\hline Lymphadenopathy (12) & $9(75)$ & $3(25)$ & $9(75)$ & $3(25)$ & $10(83.3)$ & $2(16.7)$ \\
\hline Splenomegaly (12) & $9(75)$ & $3(25)$ & $10(83.3)$ & $2(16.1)$ & $11(91.6)$ & $1(8.3)$ \\
\hline Uveitis (12) & $6(50)$ & $6(50)$ & $8(66.6)$ & $4(33.3)$ & $9(75)$ & $3(25)$ \\
\hline
\end{tabular}

* IFAT - Imunofluorescent Antibody Test.

et al., 1996; WEN et al., 1997), however, none of the studies correlate DNA detection with rickettsemia.

Many authors already described the superior sensitivity and specificity of PCR in diagnosing ehrlichiosis when compared to serology (IQBAL et al, 1994; WEN et al., 1997) because serology cannot distinguish current infection from either exposure without the establishment of infection or previous infection (IQBAL et al., 1994), and titers remained high for an additional period of more than 11 months (HARRUS et al., 1998). However, when we compare direct and indirect methods to detect $\boldsymbol{E}$. canis, a greater number of serological positive samples were observed in relation to $\mathrm{nPCR}$. Occurrence of positive serology and negative nPCR samples may be an indication of the carrier state or treatment of the animals, because dogs with anti-E. canis antibodies may not carry the parasite. Negative nPCR results may also be explained by the capacity of this parasite to "hide" in splenic macrophages(HARRUS et al., 1998).

Among the 30 examined animals, 28 dogs were positive in at least one test, thus we conclude that they were infected or previously exposed to $\boldsymbol{E}$. canis. The sample presenting $\boldsymbol{E}$. canis morulae was IFAT and nPCR positive, therefore, this dog was in an acute stage of infection.

An important percentage of pancitopenic or anemic dogs were serologically positive and nPCR negative. Pancitopenia, anemia and leukopenia were already described in acute and chronic stages (CASTRO et al., 2004). Serology positive and nPCR negative animals are at a chronic stage when cells are reduced due to bone marrow damage and $\boldsymbol{E}$. canis is in the tissue and, therefore, they are not nPCR detectable. All animals with leukocytosis were nPCR positive, and 50\% were also serologically positive. These animals could be in acute stage of infection, because leukocytosis may occur in the first 2 or 3 weeks due to bone marrow hyperplasia.

Serology and nPCR are the most suitable tests to confirm the diagnosis of canine ehrlichiosis, however it should be always treated as a complementary data to clinical and hematological evaluation. For the best interpretation of laboratory results, it is important to consider the stage of infection and the limitations of

Table 3 - Association between hematological signs and IFAT, Dot-ELISA and nPCR results from naturally $\boldsymbol{E}$. canis infected dogs examined at the Veterinary Teaching Hospital, UNESP, Jaboticabal, SP, Brazil.

\begin{tabular}{llllllll}
\hline & \multicolumn{4}{c}{ Serology } & \multirow{2}{*}{ nPCR (\%) } \\
\cline { 2 - 6 } Hematological signs & \multicolumn{2}{c}{ IFAT (\%) } & \multicolumn{2}{c}{ Dot- ELISA (\%) } & & \\
\cline { 2 - 7 } & \multicolumn{2}{c}{ Positive } & Negative & Positive & Negative & Positive & Negative \\
\hline Pancitopenia $(\mathrm{n}=8)$ & $5(62.5)$ & $3(37.5)$ & $6(75)$ & $2(25)$ & $3(37.5)$ & $5(62.5)$ \\
Thrombocytopenia and anemia $(\mathrm{n}=13)$ & $7(53.8)$ & $6(46.1)$ & $9(69.2)$ & $4(30.7)$ & $10(76.9)$ & $3(23)$ \\
Leukocitosis $(\mathrm{n}=4)$ & $2(50)$ & $2(50)$ & $2(50)$ & $2(50)$ & $4(100)$ & $0(0)$ \\
\hline
\end{tabular}

* IFAT - Imunofluorescent Antibody Test. 
these tests. In acute phase, nPCR can detect $\boldsymbol{E}$. canis DNA earlier than the serological tests are able to determine the presence of anti-E. canis antibodies. Additionally, DNA cross-reaction is uncommon in nPCR, while false positives can occur in serology, due to cross-reaction with other ehrlichial species or to persistent antibodies titers post-treatment. However, a large number of serological positive and nPCR negative samples suggest that serology is the most appropriate test for the diagnosis of $\boldsymbol{E}$. canis natural infection in dogs, especially in the chronic stage, when $\boldsymbol{E}$. canis is rare in circulating blood.

\section{ACKNOWLEDGEMENTS}

We would like to thank the Fundação de Amparo à Pesquisa do Estado de São Paulo FAPESP (02/13562-2) and Coordenação de Aperfeiçoamento de Pessoal de Nível Superior (CAPES) for financial support. We also thank Rosane Oliveira for the helpful technical assistance.

\section{REFERENCES}

CADMAN, H.F. et al. Comparison of the dot-blot enzyme linked immunoassay with immunofluorescence for detecting antibodies to Ehrlichia canis. Vet Rec, v.135, p.362, 1994.

CASTRO, M.B. et al. Experimental acute canine monocytic ehrlichiosis: clinicopathological and immunopathological findings. Vet Parasitol, v.119, p.73-86, 2004.

COHN, L.A. Ehrlichiosis and related infections. Vet Clin North Am: Small Anim Pract, v.33, n.4, p.863-884, 2003.

COSTA, J.O. et al. Ehrlichia canis infection in dog in Belo Horizonte, Brazil. Arq Esc Vet UFMG, v.25, p.199-200, 1973.

DAGNONE A.S. et al. Ehrlichiosis in anemic, thrombocytopenic, or tick-infested dogs from a hospital population in South Brazil. Vet Parasitol, v.117, p.285-290, 2003.

DAGNONE, A.S. et al. Phylogenetic analysis of Anaplasmataceae agents DNA detected in dog blood samples with intracellular inclusions from Jaboticabal - SP and Campo Grande - MS. In: SIMPÓSIO LATINO-AMERICANO DE RICKETTSIOSES, 2., 2006, Ribeirão Preto, Brasil. Anais... Ribeirão Preto: CBPV, 2006. p.378.

HARRUS, S. et al. Amplification of ehrlichial DNA from dogs 34 months after infection with Ehrlichia canis. J Clin Microbiol, v.36, n.1, p.73-76, 1998.
HARRUS, S. et al. Recent advances in determining the pathogenesis of canine monocytic ehrlichiosis. J Clin Microbiol, v.37, n.9, p.2745-2749, 1999.

HARRUS, S. et al. Comparison of three enzyme-linked immunosorbant assays with the indirect immunofluorescent antibody test for the diagnosis of canine infection with Ehrlichia canis. Vet Microbiol, v.86, p.361-368, 2002.

HIBLLER, C.E. et al. Rickettsial infections in dogs part II: Ehrlichiosis and infectious cyclic trombocytopenia. Comp Cont Educ Pract Vet, v.8, p.106-113, 1986.

IQBAL, Z. et al. Comparison of PCR with other tests for early diagnosis of canine ehrlichiosis. J Clin Microbiol, v.32, n.7, p.1658-1662, 1994.

KEYSARY, A. et al. The first isolation, in vitro propagation, and genetic characterization of Ehrlichia canis in Israel. Vet Parasitol, v.62, p.331-340, 1996.

McBRIDE, J.W. et al. PCR detection of acute Ehrlichia canis infection in dogs. J Vet Diagn Invest, v.8, p.441-447, 1996.

MOREIRA, S.M. et al. Detection of Ehrlichia canis in bone marrow aspirates of experimentally infected dogs. Cienc Rural, v.35, n.4, p.958-960, 2005.

MURPHY, G.L. et al. A molecular and serologic survey of Ehrlichia canis, E. chaffeensis and E. ewingii in dogs and ticks from Oklahoma. Vet Parasitol, v.79, p.325-339, 1998.

O'CONNOR, T.P. et al. Comparison of an indirect immunofluorescence assay, western blot analysis, and a commercially available ELISA for detection of Ehrlichia canis antibodies in canine sera. Am J Vet Res, v.67, n.2, 206-210, 2006 .

OLIVEIRA, D. et al. Ehrlichia canis antibodies detection by "Dot- ELISA" in naturally infected dogs. Rev Bras Parasitol Vet, v.9, n.1, p.1-5, 2000.

WANER, T. et al. Significance of serological testing for ehrlichial diseases in dogs with special emphasis on the diagnosis of canine monocytic ehrlichiosis caused by Ehrlichia canis. Vet Parasitol, v.95, p.1-15, 2001.

WEN, B. et al. Comparison of nested PCR with immunofluorescent-antibody assay for detection of Ehrlichia canis infection in dogs treated with doxycycline. Clin Microbiol, v.35, n.7, p.1852-1855, 1997. 